\title{
Options for Road Reform in New Zealand
}

\author{
Bryce Wilkinson
}

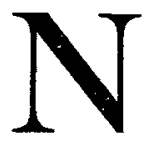
ew Zealand's 93,000 kilometre roading network is one of the country's major assets. Its depreciated replacement cost could be about NZ $\$ 20$ billion, including $\$ 5$ billion for the land (Williamson, 1994). This is comparable to the combined depreciated replacement cost of the nation's electricity, telecommunications and water supply and waste water networks. ${ }^{1}$ Although traffic densities are very low on much of New Zealand's roading network, time-of-day and/or seasonal pressure will continue to build up in some parts of the system, especially because of high current and forecast rates of economic growth.

Total road transport-related expenditure (excluding any capital charge for the roading network) is estimated to be approximately $\$ 10$ billion per annum, or about 14 per cent of GDP. Much of this road-related expenditure represents personal consumption; the transport sector itself contributes 5 per cent to GDP. Central government owns and, through Transit New Zealand (TNZ), a Crown entity, operates the $\$ 7.4$ billion, 11,000 kilometre state highway network. Local authorities are responsible for operating urban and rural roads, but receive approximately half the funds they require for road construction and operation from TNZ (see NZBR, 1993:i).

Total annual expenditures by the various arms of government on road maintenance, construction and safety are less than $\$ 1$ billion. Road users pay significantly more than this in licence fees and in petrol taxes (in the case of private motorists) and axle-weight-based road user charges (in the case of the trucking industry) (see NZBR, 1993:108).

In the last decade, New Zealand has implemented extensive and far-reaching institutional reforms as the Crown has sought to reduce debt and improve economic efficiency. Many such reforms have involved putting state-owned enterprise (SOE) providers on a competitively neutral basis. The benefits from this approach have been sufficiently encouraging to warrant consideration of its further application to the provision of road network services (see NZBR, 1992:1-34). The case for reviewing the current system for providing roads is strengthened by the need to con-

\footnotetext{
${ }^{1}$ Based respectively on the Ministry of Commerce's statistical tables for electricity, Telecom's 1993 annual report and Davin (1993).
} 
sider the organisational arrangements that will allow New Zealand to take advantage of rapidly evolving electronic transport-related technologies.

\section{Divided Responsibilities and Conflicting Objectives}

The responsibility for making roading decisions falls overwhelmingly on the government because the road system is entirely owned and operated by public agencies and the government controls all the key road pricing decisions.

Territorial authorities' involvement in roads reflects a time when local access considerations were paramount, while Crown ownership of state highways emerged in the 1930s in response to a clear need for consistent standards along national highways. But this division of responsibilities arguably fails to establish sufficiently clear lines of responsibility and accountability or to take due account of problems of incentives and inadequate information. For example, TNZ and territorial authorities each have the power to regulate road use and safety standards, and to plan, design and oversee the construction of new roads. But the accountability of territorial authorities to the ultimate owners of these roads (tax-and rate-payers) is reduced by TNZ's power to establish and to change the designation of roads and to change the jurisdiction under which these roads fall. In addition, divided responsibility has led to an extremely bureaucratic system for coordinating and approving the annual programs of the diverse public authorities. Road safety is another area where divided responsibilities could impair outcomes. TNZ is responsible for road expenditures that affect network safety, but the Ministry of Transport is responsible for licensing drivers, setting standards for the types of motor vehicles that may be used on roads, and for regulating driving behaviour. This separation creates incentive problems. For example, the Ministry of Transport's incentive to regulate vehicle standards optimally may be reduced because it cannot directly influence the type of roads that are constructed, does not bear the costs of maintaining these roads and does not lose revenue from reduced road usage if it unduly raises motorists' costs in meeting vehicle and driver safety requirements.

Conflicting objectives imposed on TNZ create further problems. TNZ's primary objective, as defined in the Transit New Zealand Act 1989, is to 'promote policies and allocate resources to achieve a safe and efficient land transport system that maximises national economic and social benefits'. Thus, TNZ is required to determine the optimal trade-offs among safety, transport efficiency, and national economic and social benefits. This is a near-impossible task, for several reasons. First, the safest road system is unlikely to be the most efficient; but how is TNZ to determine the extent to which safety should be compromised? Second, operating a land transport system so as to maximise national economic and social benefits would require TNZ, in principle, to consider the extent to which safety and/or efficiency in the land transport system should be sacrificed in order to compensate for inefficiencies elsewhere in the economy. Clearly TNZ has no comparative advantage in terms of information, or statutory powers, to undertake this task.

In practice, compromises among such conflicting objectives emerge through the political and bureaucratic processes that dominate the current structure. But TNZ 
has no clear guidelines for determining that these trade-offs are optimal. Monitoring agencies are similarly unlikely to be able to evaluate TNZ's performance.

TNZ's incentives to manage the roading network in an efficient manner are likely to be further weakened by the protection against competition that is conferred by current legislative barriers to entry and by funding arrangements that would penalise potential private entrants to the roading industry.

The benefit-cost analyses that TNZ uses (of necessity) in making investment decisions are plagued by inadequate information. Contentious aspects of these analyses include the values assumed from savings in travel time and in human lives and the degree to which such values reflect average or marginal benefits. In recent years TNZ has been able to fund only those projects with a benefit to cost ratio of around 5:1. Such a wide margin implies that those making the funding decisions have little confidence in the calculations or that viable projects are not being undertaken. The necessity for such an approach demonstrates that much of the information about willingness to pay that private firms would utilise in making similar decisions is not currently available.

This analysis suggests that savings may be available from greater clarity in management objectives, clearer demarcation of powers over the roading network, a more decentralised and less rigid planning process, and the removal of legislative and funding barriers to entry to the roading market.

\section{Reform Options}

New Zealand's reforms in recent years have aimed to make efficiency the prime objective of the provider of a service. An efficient land transport system would allow diverse consumer wants to be met at least cost. When users are confronted with the costs of their actions, their choices reflect a balancing of benefits and costs. Outcomes are likely to be efficient if prices reflect all social costs and those costs have been minimised as they would be if producers had to set competitive prices.

In New Zealand, efficiency has often been pursued by requiring the Crown provider to operate as a successful business, in a contestable, competitively neutral environment. The Crown remains independently responsible for the quality of its regulatory policies, such as those relating to monopoly or externality issues. The SOE reforms have demonstrated that considerable efficiency gains can be derived and accountability much improved from assigning a single, over-riding objective to any given entity (though privatisation is likely to be necessary to lock in such gains). These considerations inform the reform options discussed below.

Options for improving the economic efficiency of the roading network include: a limited evolution of the status quo; the commercial operation of publicly-owned roads through a SOE structure; and private ownership and operation of roads. The timing of the two latter reforms would depend on the gathering of further information and the development of cost-effective billing technologies (discussed below). As well, complex issues of property rights, regulation (for safety and/or monopoly), billing systems and financial structure and monitoring arrangements need to be addressed. 
The New Zealand Business Roundtable (1993) has considered two options for commercialising the public road network. One option would assign ownership and commercial objectives to TNZ only for the current state highway network, with the Crown holding all shares in TNZ. Under the second option, this assignment would be extended to all roads, with both the Crown and local authorities holding shares in TNZ in proportion to their relative historical contributions to the road network.

The more limited state highway option would be easier to implement in that the Crown is the dominant owner of the asset. It could also reduce concerns about monopoly power over the roading network, since monopoly power is a more serious problem for local roads, whose ownership would not have changed. One disadvantage is that it might be harder to introduce new technology (like tolling systems) in a consistent fashion across the entire road network. Furthermore, it may lead to continuing contractual problems between (non-commercial) local authorities and (commercial) TNZ. De facto corporatisation of local roads may result from the funding constraints faced by local authorities, and this may occur in a less consistent fashion than if commercial operation of all roads were undertaken within one institution.

The more ambitious option of commercialising all roads would provide markedly greater potential economic benefits than the more limited corporatisation option. The most efficient industry structure (perhaps regional commercial operation of roads) could evolve from the initial commercialised operation. However, this approach may be harder to implement and would surely exacerbate concerns about monopoly operation of roads.

\section{Revenue}

Irrespective of which reform option is adopted, a greater commercial emphasis in roading management would raise several policy issues, including the need to collect a greater proportion of revenue directly from road users, and questions concerning property rights and regulation.

Unlike in the case of other SOEs, the provision of road services would derive revenue from taxing a necessary roading input (petrol) and applying a form of charge to heavy vehicles rather than charging directly for the services provided by TNZ. Because many road expenditures may reduce fuel consumption - for example, straightening or levelling a road may reduce fuel consumption per trip the petrol tax is flawed as a mechanism for revealing consumer preferences. In particular, fuel taxes and road user charges do not facilitate the discovery of user preferences with regard to congestion, safety, surface quality and willingness to pay for fewer bends and hills. Nor do they allow prices to vary with the intensity of demand, as may be necessary in common-cost situations (Kahn, 1990:85).

Both the SOE model and private operation of roads would involve direct charging of road users rather than using taxes. Except as a transitional arrangement, neither the SOE nor private roading firms would have access to fuel tax revenue, since the power to tax is inconsistent with competitive neutrality. Assuring an SOE of tax funding would reduce its incentives to search for billing systems that would 
facilitate discovery of consumer preferences. Reforms to the roading system therefore need to take into account the feasibility of direct billing for road network services. Fuel taxes are very economical to collect and do not impede the flow of traffic; and the New Zealand experience has highlighted the inconvenience of paying manual tolls on roads. Yet the advanced electronic billing systems currently being developed in a number of countries do not impede traffic flows and have the potential to increase radically the options for managing road systems. Norway and Singapore have already implemented cordon pricing for entry into the city centre, while many others, such as Hong Kong, the Netherlands, the United Kingdom and Sweden have studied the feasibility of such action (Dunlop, 1994:1). Singapore is currently testing an electronic billing system that would bill motorists for using streets. In South Africa, a privately owned company, Tolcon, which operates 400 kilometres of highway roads, has run a pilot project to collect tolls by means of a microwave device that reads a tag on the front windscreen of vehicles. The direct capital cost of the system is around NZ $\$ 45,000$ per toll lane; each tag costs around $\$ 10$. Billing costs could be as low as 2.5-5 per cent of the toll fee (private communication with the company).

If a new billing technology were judged to be viable for the network as a whole, it is very important that all decisions concerning its implementation be as commercially driven as possible. If an SOE were established, it could rely for a transitional period on imperfect systems of funding for the road network (such as the current fuel tax or shadow billing) while it developed and implemented its preferred billing system. Such taxes could be phased out under a timetable that encouraged the SOE to develop a replacement billing system expeditiously.

To maximise efficiency, an electronic billing system should be introduced as soon as technological change has reduced the costs below the likely savings from improved future network decisions. Given the capital intensive nature of the road network, large savings could accrue from better information for making investment and maintenance decisions. Direct measurement of consumer willingness to pay for different roads would provide a valuable new source of management information.

The optimal network charging system may involve separate fees for access and charges for use. An efficient billing system may lead to better utilisation of the network than a petrol tax, which discourages extra mileage even in those parts of the network that are already underutilised.

\section{Property Rights and Regulatory Issues}

Commercial operation of roading could involve a reallocation of property rights that might, in isolation, be considered socially undesirable. For example, certain rural roads may not be commercially viable if maintained to their current high standards. But alternative policies and instruments could be both more effective and more efficient in providing quality: for example, income support could be targeted to affected road-users. 
Current external regulation of road use and safety standards does not provide a basis for assessing the optimal level and extent of safety regulation. Cost-effective voluntary monitoring and information disclosure by road users and commercial road suppliers would be more likely to supply the optimal level of road safety at least cost, so long as road users and suppliers had some ability to sue the appropriate counterparty for breach of contract.

Property rights in relation to safety have the potential to critically affect outcomes. Incentives are likely to be markedly sharpened if the road operator and/or enforcement authorities can be readily sued for failure to perform duties adequately. Palmer (1993) notes that a common law rule applies in New Zealand that protects local authorities from liability for any damage resulting from ordinary disrepair of a road or footpath (a similar immunity was abolished in Britain in 1961). ${ }^{2}$ Given well-defined legal liabilities, self-regulatory powers for road use should be immediately transferred either to TNZ operating as an SOE or to private road operators so that they can take effective measures to manage their risks.

The regulatory structure for obtaining environmental clearance for road projects in New Zealand is governed by the Resource Management Act (RMA). Theoretically, the provisions of the RMA would apply equally to all participants in the road network industry, public as well as private. But, in practice, as planning agencies are unlikely to sanction widespread duplication of the existing network, this is likely to leave new entrants in an uncompetitive position compared with existing network operators. (This problem is not unique to roading and could justify a general review of the economic impact of environmental legislation.)

Monopoly issues are likely to be a more serious problem for local roads. Monopoly power in the inter-urban highway market would be reduced by inter-modal competition (air, sea, and rail) and, depending in part on the RMA and local geographical factors, over time by the emergence of competing rival motorways and bypasses in some locations. But fewer opportunities exist in respect of local roads.

Monopoly power does not necessarily justify regulation of roading suppliers. Although unregulated monopoly operation can impose economic costs through restricted output and higher prices, regulatory intervention may not provide benefits in excess of costs, because of the lack of information available to regulators and incentive problems created by external regulation. The choice between regulated and unregulated monopoly supply of road network services is a choice between two potentially inefficient outcomes.

The Commerce Act provides a general structure for regulating monopoly power that may be used in preference to industry-specific regulation of roading. A wait-and-see approach to regulation could be employed for roading; but it may create greater uncertainty regarding the future extent and quality of regulation than preemptive initial regulation. Unified network-specific regulation of the roads may therefore be justified if monopoly power did emerge as a significant problem or if

2 I am grateful to Greg Dwyer for drawing my attention to this source. 
regulatory intervention was adopted in a piecemeal fashion under the Commerce Act.

On the other hand, the New Zealand experience to date with the commercialisation of electricity indicates that users of a major monopoly's services can have enough political influence to make it difficult for prices to attain, let alone exceed, long-run marginal cost.

Given these doubts about the degree to which a single provider would, in practice, be willing or able to extract monopoly profits, a wait-and-see approach should be taken seriously and evaluated in conjunction with decisions taken in relation to the reallocation of property rights more generally.

\section{Private Roads}

Once commercial operation and the regulatory environment for roading were established, there might be no strong rationale for continuing public ownership of roads, especially as long-standing international examples exist of privately-operated roads. Furthermore, private-sector participation in roading is becoming more common in both developed and developing countries (though more often as a result of public-sector funding constraints than of efficiency considerations). Argentina, Brazil, Mexico, the United Kingdom and Germany either have privatised some existing roads or are considering doing so. The United Kingdom intends to use shadow tolls until electronic tolling is viable (Dunlop, 1994:3).

International experience demonstrates that public-sector intervention in the private operation of roading increases the risks of failure of privately-owned road infrastructure as a result of reduced commercial flexibility (NZBR, 1993:90-1). The greater commercial focus of private ownership and the enhanced monitoring of roading management under private ownership suggests that, as long as monopoly costs (including the costs of regulations) are not severe, corporatisation of New Zealand roading infrastructure would provide even greater economic benefits if it led ultimately to private ownership of the roading network.

\section{The 'Crown Agency' Model}

If the costs of electronic billing should turn out to be prohibitively expensive well into the future, attention would turn to the options for reform based on separating the role of the Crown as a purchaser of roading services from its role as a provider. This would involve difficulties like specifying the detailed attributes of the roading service that the Crown would purchase, trying to ensure contestability in the provision of road network services, and monitoring TNZ's performance in this respect. However, this alternative 'Crown agency' model could yet be more efficient than the current system of road management.

A transparent, arms-length funding arrangement is one possible way to ensure some separation of commercial objectives from other political objectives. A commercial roading company, whether publicly or privately owned, could generate revenue from its roads without adopting electronic billing if the Crown paid a 
'shadow' toll (a toll per vehicle using the company's infrastructure) to the company. Funds for the shadow tolls could be provided from licence and registration fees, petrol taxes and road-user charges. This approach could ease the costs of moving to a new funding mechanism, but would not remove the information problems inherent in the current benefit-cost ratio approach.

\section{Concluding Remarks}

Many challenges lie ahead for the organisation of the New Zealand roading system. A reasonable prima facie case can be made that current outcomes are likely to be inferior to alternative approaches that better harness incentives and decentralised information and minimise conflicts between institutional objectives.

The New Zealand Business Roundtable (1993) report provides an agenda for further research and development of reform options. But the questions of how far and how fast to move and of the matters of detail are very much subject to debate, clarification, and evolving technological developments. Yet the approaches canvassed in this article will endure. Worldwide, private-sector involvement in roading is growing apace.

\section{References}

Davin, T. (1993), 'The Water and Wastewater Monopoly in Local Government', Poirura City Council (Research Paper MAPP 501).

Dunlop, R. (1994), Speech to the LGA Conference, Palmerston North, June 10-13.

Kahn, A. (1990), The Economics of Regulation: Principles and Institutions, Vol. 1, MTT Press, Cambride, Mass., and London.

New Zealand Business Roundtable (NZBR) (1992), The Public Benefit of Private Omnership: The Case for Privatisation, Wellington, June.

- (1993), Options for the Reform of Roading in New Zealand, Wellington, June.

Palmer, K. (1993), Local Government Law in New Zealand, Law Book Company, Auckland.

Williamson, M. (1994), 'Opening Address', in Transit New Zealand, Proceedings of the New Zealand Land Transport Symposium '94, Vol. 3, Wellington.

This article is an edited version of a paper presented by the author in August 1994 to a New Zealand Land Transport Symposium organised by Transit New Zealand. That paper was in turn based on a much longer CS First Boston report 'Options for the Reform of Roading in New Zealand' for the New Zealand Business Roundtable, June 1993. Chris Meades was a principal author of the 1993 report. 